\title{
СИНТЕЗ И СВОЙСТВА 1,3-ДИЗАМЕЩЕННЫХ МОЧЕВИН - ПОТЕНЦИАЛЬНЫХ МУЛЬТИТАРГЕТНЫХ ИНГИБИТОРОВ РАСТВОРИМОЙ ЭПОКСИДГИДРОЛАЗЫ (SEH) И ЦИКЛООКСИГЕНАЗЫ (СОХ)
}

\author{
Б.П. Гладких, В.В. Бурмистров, Г.М. Бутов \\ Кафедра химии, технологии и оборудования химических производств ВПИ (филиал) \\ Волгоградский государственный технический университет, \\ 404131, Россия, г. Волжский, ул. Энгельса, 42а.
}

DOI: 10.19163/MedChemRussia2021-2021-370

E-mail: gladkih-boris@mail.ru

В работе проведен направленный синтез 1,3-дизамещенных мочевин, содержащих в своей структуре фрагмент молекулы ацетилсалициловой кислоты в качестве липофильной группы, фрагменты других известных лекарственных препаратов, в качестве вторичных фармакофоров, а также транс-4-амино(циклогексилокси)бензойную кислоту, мочевины на основе которой проявляют высокую ингибирующую активность в отношении sEH.

$\mathbf{R}=$<smiles>CCC1CC2CCC1C2</smiles><smiles>Cc1ccccc1I</smiles><smiles>OCCC1CC2CCCC1C2</smiles><smiles>Cc1ccc(I)cc1</smiles><smiles>CC(=O)Oc1ccccc1NC(=O)NP</smiles><smiles>CC(C)C1C=C2CC3CC(C2)C1C3</smiles><smiles>CCC1CCC(Oc2ccc(C(=O)O)cc2)CC1</smiles><smiles>Clc1ccccc1Cl</smiles><smiles>Clc1cccc(Cl)c1</smiles><smiles>Cc1ccc(OC(C)(F)F)cc1</smiles><smiles>Cc1ccc(-c2cc(C(F)(F)F)nn2-c2ccc(S(=O)(=O)O)cc2)cc1</smiles>

Синтез 1,3-дизамещенных мочевин проводили в среде ДМФА при комнатной температуре в течении 12 час. Выходу продуктов составили от 46 до 85\%. Структуры полученных соединений подтверждали методами хромато-масс спектрометрии и ЯМР-спектроскопии.

Замена липофильной группы на фрагмент молекулы аспирина позволило снизить коэффициент липофильности полученных соединений, что, по-видимому, будет благоприятно сказываться на их водорастворимости.

Полученные 1,3-дизамещенные мочевины могут являться мультитаргетными препаратами, то есть проявлять ингибирующую активность не только в отношении растворимой эпоксидгидролазы SEH, но и влиять на синтез простагландинов, путем подавления двух изоформ фермента циклооксигеназы.

Работа выполнена при финансовой поддержке Российского научного фонда

(грант № 19-73-10002).

$$
-370-
$$

